\title{
The role of the tenement housing development in the urban structure of Western and Central Ukraine during the Secession era
}

Abstract

The principles of the formation of the urban planning space of cities of Western and Central Ukraine during the period of Secession, the role of profitable residential development in the city structure are analyzed. The differences between the Se-

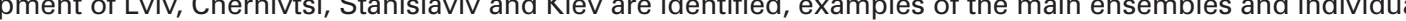
buldings are given. Using the example of the house of architect Wiadysław Horodecki (the so-called House with Chimaeras) we have highighted the specific features of restoration of buildings of the era of Secession.

\section{Introduction}

Since the second half of the 19th century, in the residential development of the cities of Ukraine, it was observed the multi-stylishness that was manifested in the application of elements of the past styles. Since that the then Malorociia has increased, and these trends have spread significantly during the domination of the Art Nouveau style, due to the practice of teaching architects from Ukraine in St. Petersburg (in the territories under the Russian Empire), and in Austria-Hungary and Poland (on the territories of the Austro-Hungarian Empire). The integration of the territories of Ukraine into the pan-European process of development of architecture in 1911-1917 was facilitated by the practice of conducting all-Ukrainian art exhibitions and organization of competitions for the design of outstanding public buildings, in which prominent Ukrainian and foreign architects took part. At the same time, despite such involvement in the pan-European processes and international contacts, due to the fact that the Secession fell on the territory through the ciries of Austria, Poland, $\mathrm{H}$ Mngary, it be through the ciles of Austria, Poland, Hungary, it becombining with the existing a seconchitectural traditions and accordingly modifying itself under their influence which is especilly noticeable in the examples of the tenement housing development in the cities.

1. Analysis of the urban planning space of the Secession era in the provinces of the Austro-Hungarian Empire If we analyze the urban space of the cities of the SeRussian empires, it is noticeable that the urban develop- ment of Lviv, Chernivtsi, Stanislaviv are more simiThereas there is a noticeable difference among the buildings of Kyiv, Kharkiv, Odessa, and also, for example, between Kyiv and Vinnytsia.

The fact that the territory belonged to the AustroHungarian Empire caused the spread of urban planning principles of the reconstruction of Vienna, the capital, in the epoch of capitalism development to the capitals of the provinces of Galicia ( Lviv) and Bukovyna(Chernivtsi) $[2-4 ; 13-17 ; 20 ; 21]$

The formation of neighbourhoods of concentrated ecession tenement buildings in Lviv, outside the medieval city, occurred directly under the influence of the then large-scale urban-planning activities. They laid new streets and boulevards, increased We area of private residential lots in comparison with the medieval center. The built-up density and the number of stories in buildings increased as well. (III. 1).

The specificity of Lviv tenement housing development in the Secession era is the integrity of the chially that often the whole stret was built up py the sam architectural bureau or architect (the per and the ensemble of Domagalych Street (Acad. Pavlov St) ensembles along Hlynianska Street (D. Dontsov St), Friedrich Street (Martovych St), Yablonovski Street (Shota Rustaveli St), Bonifratry Street (M. Kravchuk St), Lenartovych Street (Nechui-Levytskyi St.) (III.1).

The further development of the engineering network system made it possible to increase the scale of the tenement housing development to the leve

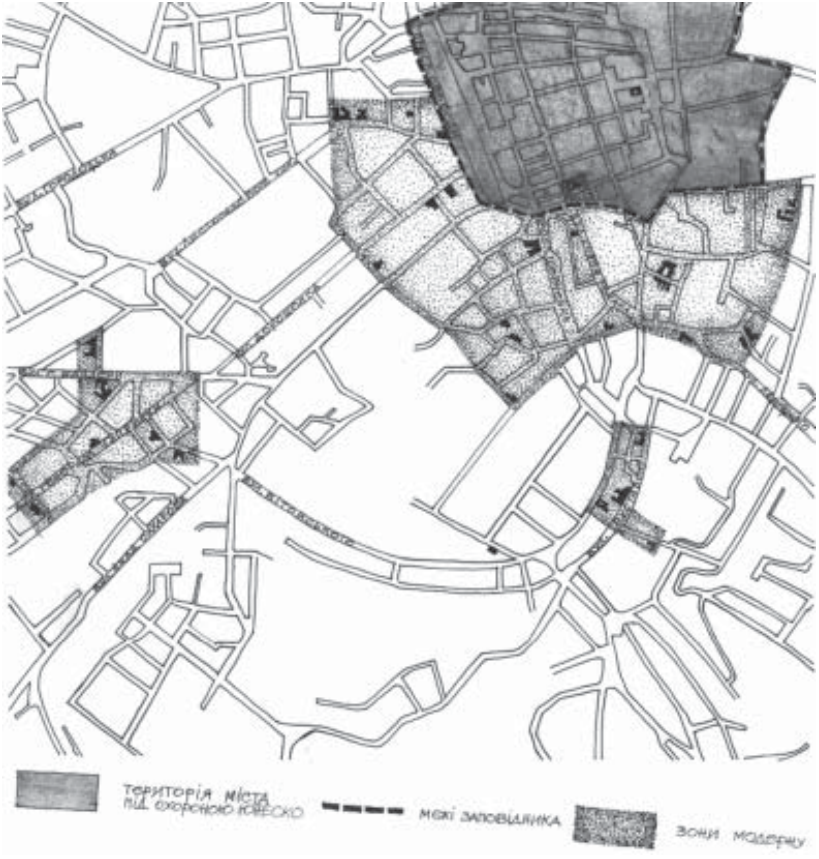

III. 1. The location of the Secession zones on the plan of Lviv (Scheme
of Yu. lvashko)

of large tenement buildings complexes (groups of two three-story houses on Kotovskyi Street, 6-12 in the form of a square; Rondo Complex of twelve one-section houses and a public garden on Akademik Bogomolets Street) $[6-8 ; 10 ; 11 ; 18-19 ; 23 ; 27]$.

At the same time, the analysis of residential development in Lviv in the Secession era, indicates the absence of a general development program for the city at that time. Despite the cardinal urban-planning activities, the medieval narrow parceled principle of development - building up the frontage lines - still prevalis within the historica center. Similar urban planning processes were in Chernivtsi, the capital of the Austro-Hungarian province of Bukovyna. The study of the construction of Chernivts involved various scientists [24-26]. The location in the center of Chernivsi of new administralive, cultural and educational buildings stipulated the concentration of the residential buildings of the Secession style along the central streets. The construction of the rallway station in the Art Nouveau style on Vokzalna Street (now Yu. Gagarin Street) contributed to the emergence of another center In In the ef the doc Squar Street and Ruska Street were formed in Chernivsi. And the main number of the Secession buildings were the tenement buildings, whose architectural appearance was influenced by the traditions of historicism-eclecticism which is generally typical of the tenement buildings of the Secession era in the cities of Western Ukraine.

Comparison of the urban development of the capitals of the then Austro-Hungarian provinces - Lviv and Chernivtsi - in the era of domination of Secession, shows the existence of such common features as the formation of new urban centers outside the historic city; the high density development; construction activities are carried out along the red lines without gaps between the houses; construction according to the closed building method with inner "courtyards-wells" and long tiers of galleries between the Thartments from the side of a courtyard.

The traditions of the "Viennese architectural school", dominated both - in Lviv and in Chernivtsi in the late 19th - early 20 th centuries. Althoug there is also a stylistic connection with the arch-

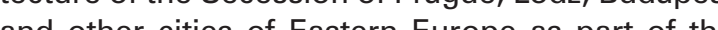
Austro-Hungarian Empire. Prage and Budpest to Luivand Chernivtsi, opening branches of foreign banks in the Secession styin the cities of Western Ukraine (the Savings Bank Board in Chernivtsi, the Czech Bank in Lviv), served to continue the main European urban-planning trends of the Secession domination period. In the cities under the rule of the Russian Empire, there was a practice of inviting Petersburg and Moscow architects - M.V. Vasyliev, F.I. Lidvall, F.O. Shekhtel, R.-F. Meltser, O.I. von Gauguin, Ye.L. Morozov. The tenement housing development of the Secession period in the cities of Western Ukraine was concentrated, including within entire streets or residential complexes, in the cities of Centra and Eastern Ukraine - mainly as separate objects in the background development of historicismeclecticism.

Despite the dominant role of the public objects of ning space of the late $19 t h$ - early 20 ch centuries (the "Dniester" insurance company, the Chamber of Commerce, Narodna Hostynytsia" hotel, the T. Balaban's insurance company in Lviv, the Savings Bank Board, the city theater, Railway Administration Office in Bukovyna, Bristol hotel in Chernivt$\mathrm{si}$, and etc.), the medium and high-rise tenement verildings development was the main scale of development of the city blocks. A comparison of the urban planning measures carried out in the era of nivtsi and Stafthe Secession style in LViv, Chering trends within the Austro-Hungarian Emple: - expanding the boundaries of the city and the inclusion of suburban areas;

- introduction of a new layout due to the demolition of the medieval defensive walls and the formation of green boulevards in their place;

- the formation of new urban centers outside the historic center (this principle, in accordance with the model of Vienna, was introduced in Lviv and Stanislaviv

- a departure from the medieval narrow parceled principle of development towards thecapitalist urban-planning with an increase of the size of plots and the scale of development; 

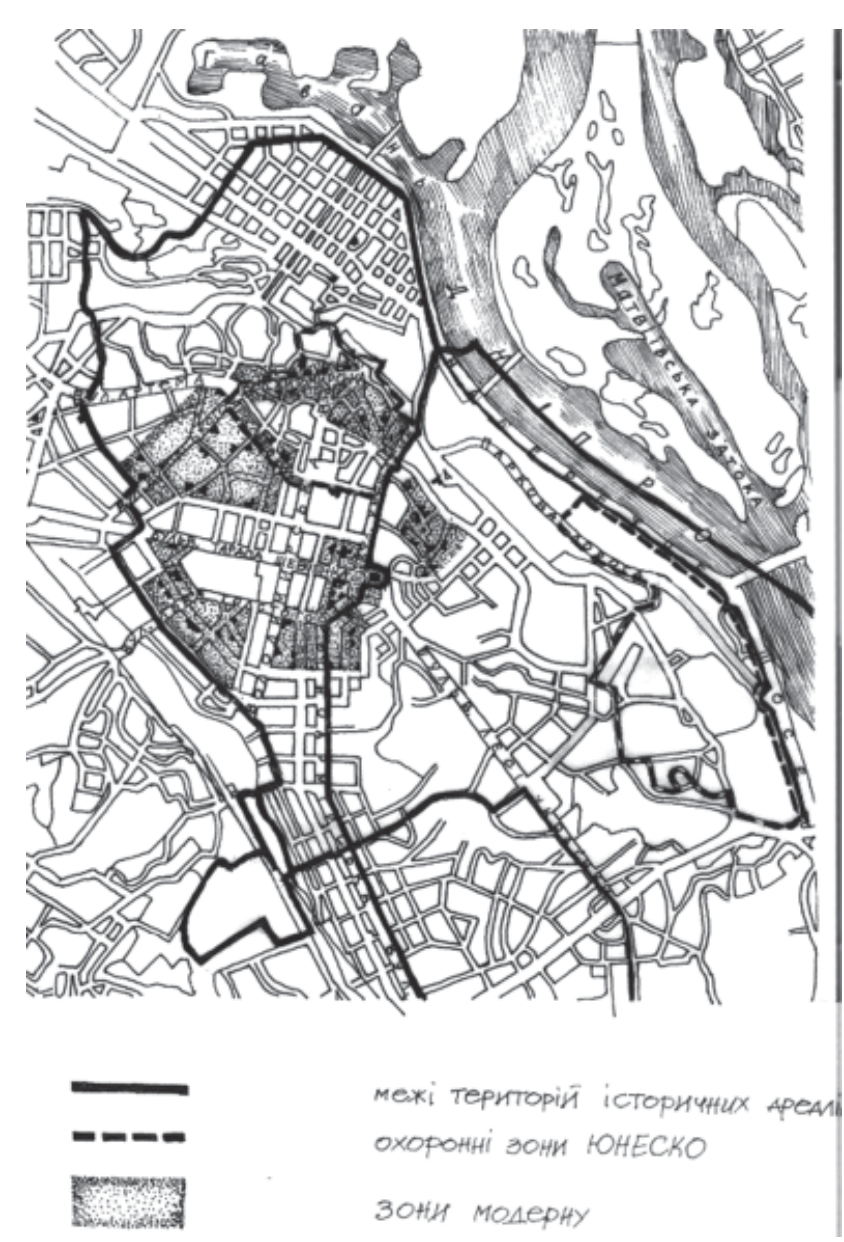

III. 2. The location of the Secession zones on the plan of Kyiv (Scheme
of Yu. Ivashko)

- development of the city in many directions;

a variety of location of buildings in the ribbon and ngle building (separate buildings, semi-detached buildings, row and angle buildings)

the application of the new principles of the formation quarterly developmen

A the commonness of Vienn

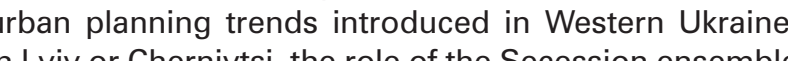
development in the urban spece proved to be greater than in Vienna itself, where only a few symbolic objects

. The urban planning space of the Secession period in the territories governed by the Russian Empire

Like the cities of Western Ukraine, the architecture of the Secession style of the cities that belonged to the Russian Empire was also directly influenced by the tendencies of historicism-eclecticism, which led to the lack of stylistic purity, especially in private tenement housing construction. It should also be noted the dominant role of the administrative requirements in the formation of the city development of Kyiv at that time, since the streets of Kyiv were divided into four categories, regulating the appearance of the street facing facade, because, most often, all the courtyards facades had unpresentable "casual" character.

"Considering that the Secession city development equired much more funds than, for instance, $t y-$ pical residential building of the period of historicism-eclecticism; this led to the fact that tenement houses in the Secession style, constructed on the streets and squares of the first and second leve should be brick, and had no less than two floors, should be built on individual projects and approved in the City Duma with the supervision of construction (III. 2).

, correspondingly, influenced their scale and architectural image and, at the same time, the impact ment.

The highly creative phase of the Secession style in Kyiv, coincided with the period of the nextyle in struction boom", which, in turn increas buitdensity and led to an increase in the number of floors of buildings, changing the vector of city building (III. 2). In less than a quarter of a century - from the end of the 19th century to the first decade of the 20th century - the number of floors of houses Kyiv doubled: from three to four floors to six to seven floors $[5$, p. 82,$83 ; 22$, p. 25].

Since the period of formation of a new urban center between Khreshchatyk Street, Vlolodymyrska Street and Bibikovsky Boulevard (T. Shevchenko Boulevard) coincided with the spread of the Secession style, the central streets and squares were decorated with various "author's" residential houses of this style, such as houses at Kostolna, (architect I. K. Liedokhovskyi) and Pushkinska, 21 (architect I. A. Zektser) and others. The multi-storey tenement building of Ginzburg became a decoration of the ensemble of Mykolaiivska Street on the territory of the former manor house of Mehring (now - Architect Horodetskyi Street) the ensemble was completed with a small square with a fountain in front of the Solovtsov Theater (now the theater of Ukrainian drama and comedy) above which there was a hill "crowned" with the expressive "House with Chimeras" by W. Horodeki (III. 5).

During the Secession domination, the main urban 列 electic tonement buildings of average hised the style of tradition historicism-eclecticism. Among the best Kyiv examples of street development of the Secession period, there are the neighborhoods between Pushkinska, FunduKleivska, Kreshchatyk streets and Bibikovskyi Boulevard, as well as the blocks between the streets of Velyka Volodymyrivska, Fundukleivska, Tereshchenkivska and Bibikovskyi Boulevard. During the the Secession period, development along Mariinsko-Blahovishchenska (Saksahanskyi St.), Velyka Vasylkivskay, Kuznechna (Horkyi St.) and Zhylyanska streets continued with the construction of medium
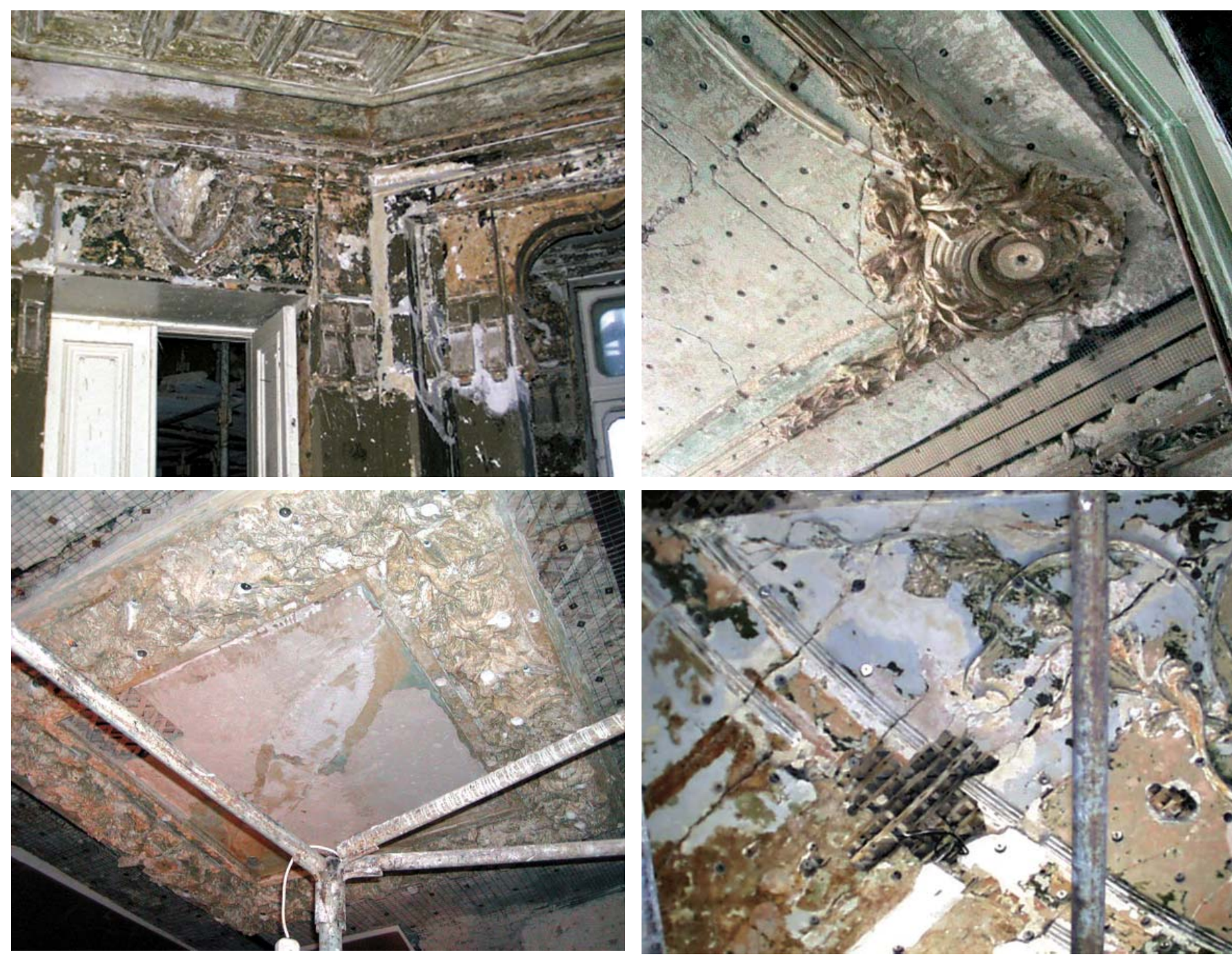

III. 3. The house at $10 \mathrm{Bankova}$ Street Condition of interiors before restortion. Photo: Ukrestavratsiia corporation, 2001-2003

and high-rise tenement buildings. At the beginning of the twentieth century, the medium and multi-storey teUper Town; the pace and scale of construction in Podol were significantly less.

The Secession houses in the central districts of the city " structures were given the appearance of urban-planning accents and dominants due to the number of floors, towers, bay windows, spires and the like. Some architects took into account the peculiarities of the unique Kyiv relief, and then created picturesque perspectives and visual connections between the objects and the relief, underlined by the stairs, terraces, bridges and ramps. At the same time, the then administrative and legal re quirements had a negative impact on the layout of private residential estates, which were built around the perimeter, leaving only a small courtyard-"well", which did not meet the standards provided for insolation and aeration.

Such drastic changes, as in St. Petersburg, were not observed in Kyiv urban-planning approaches to the for- mation of the city development of the Secession era, since the role of joint-stock and credit societies, whose signe ref jointstock and credit societless significant in Kyiv.

It should be noted that the urban planning activities is divided into three stages in Kyiv in the 19th-early 20th centuries - from the construction of separate multi-storey buildings with perimeter planning among low-rise unordered private housing development to a gradual transition to the ribbon building of sites and high-density street development of streets along the "frontage lines", and subsequently to the spread of methods of construction of parallel lines of the residential buildings connected by courtyard driveways, although, again, unlike in St Petersburg, quarter driveways and open courts of honor did not become widespread in Kyiv. Most of Kyiv tenement buildings in the Secession style were one-section houses, in which the ceremonial and "back" staircases were located along one axis. 

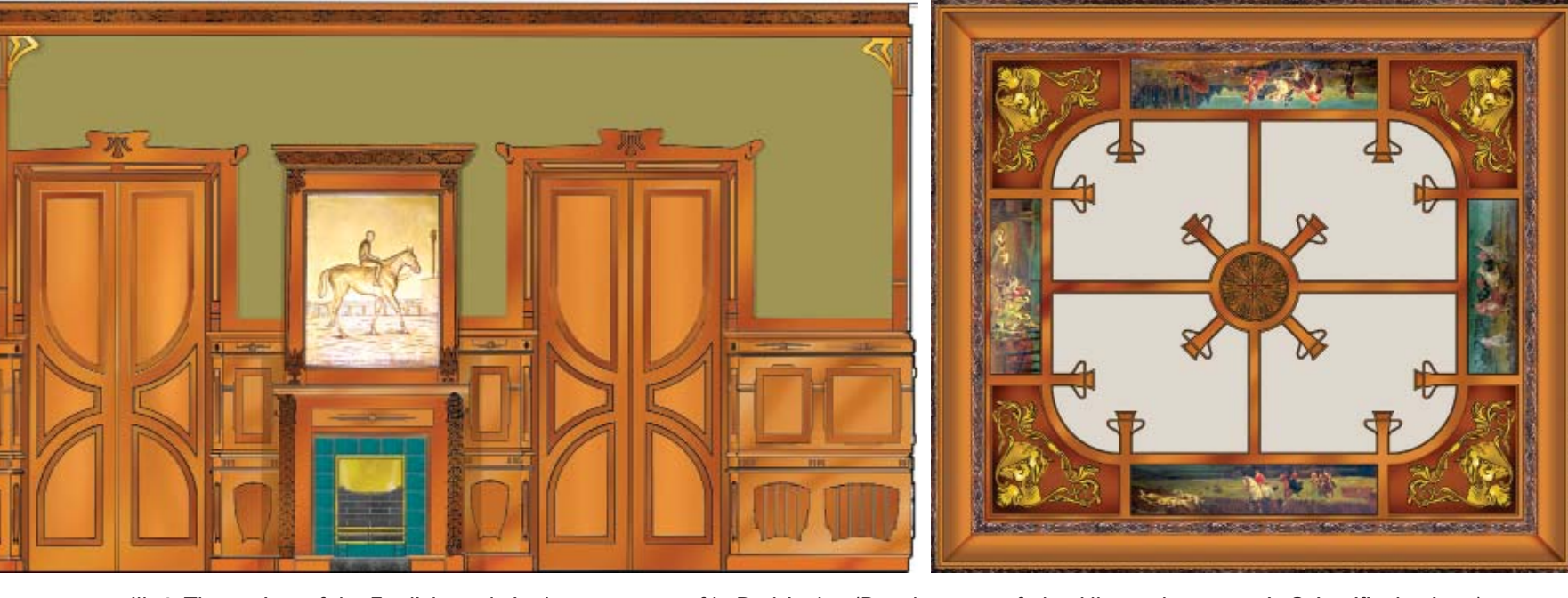

III. 4. The project of the English study in the apartment of L. Rodzianko.

3. Kyiv tenement buildings of the Secession period in the urban environment and the experience of their restoration

The specialists of the Ukrrestavratsiia Corporation have the experience of restoration of Kyiv tenement houses of the Secession era, in particular, the house of Władystaw Horodecki at 10 Bankova Street, Kachkovskyi Hospita with residential premises of the owner at 33 Gonchar Street and L. Rodzyanko's house at 14b Yaroslaviv Va

Street.

On the example of the comparison of the restoration problems that arose during the implementation of restoration activities at these three objects, we can determine
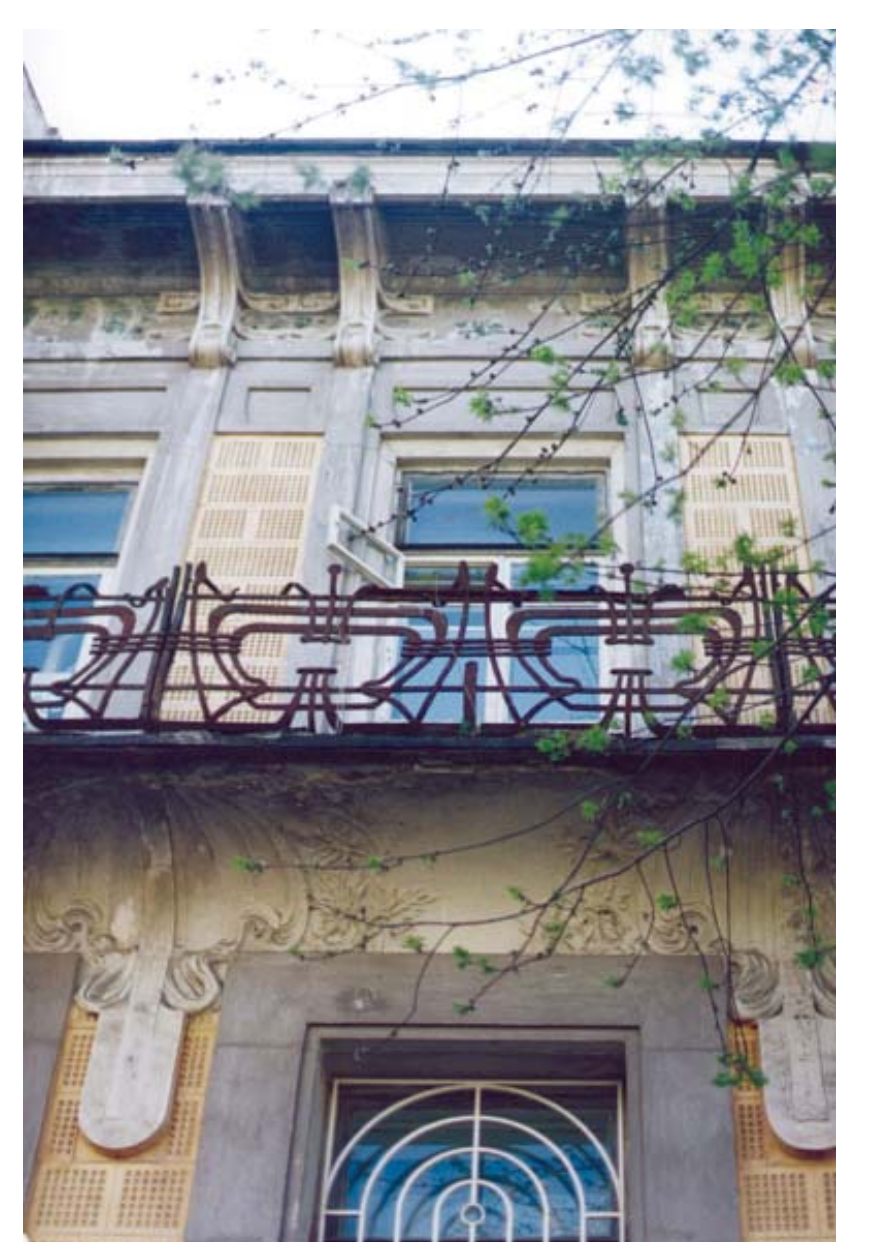
-restoration and reconstruction of the original ap- the features of the building materials and structures used during the Secession period and the causes of the emergency state of the objects, which led to a list of restoration works.

The scope of the work involved the following ob-

L. Rodzianko's house at 14b Yaroslaviv Val Street Restoration of the main facade and the apartment of the owner with the adaptation to the "Suziria" the ter in the Kachkovsky clinic at 33 Honchar Street pearance of the main facade with the strengthening of the terrace;

the building of the house of Władystaw Horodeck at 10 Bankova Street, the so-called "House with Chimeraes", - a comprehensive restoration of the building including interiors and re-profiling under the residence of the President of Ukraine (III. 3-8). Comparison of the issues and causes of the emergency state of these three houses of the Secession . condition because of construction on the crica elief, and because of applying the latest at that time structures. (III. 5).

III. 5. The Kachkovskyi linic. Photo: Yulvashko, 2009 .
a. The emaergency condition - cracks from 32 to $38 \mathrm{~cm}$,
b. The scheme of bored piles

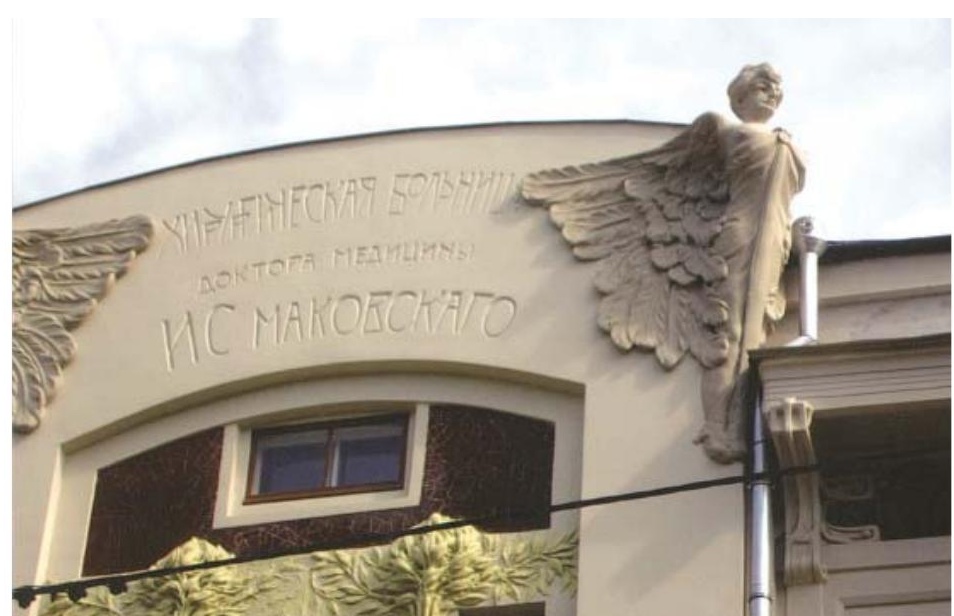

$\mathrm{C} x \mathrm{e} \mathrm{M}$ a

РОЗТАШУВАННЯ ПАЛЬ ТА ПОРЯДДК IX УЛАШТУВАННЯ НИЖН IИ ПП IДВАЛ

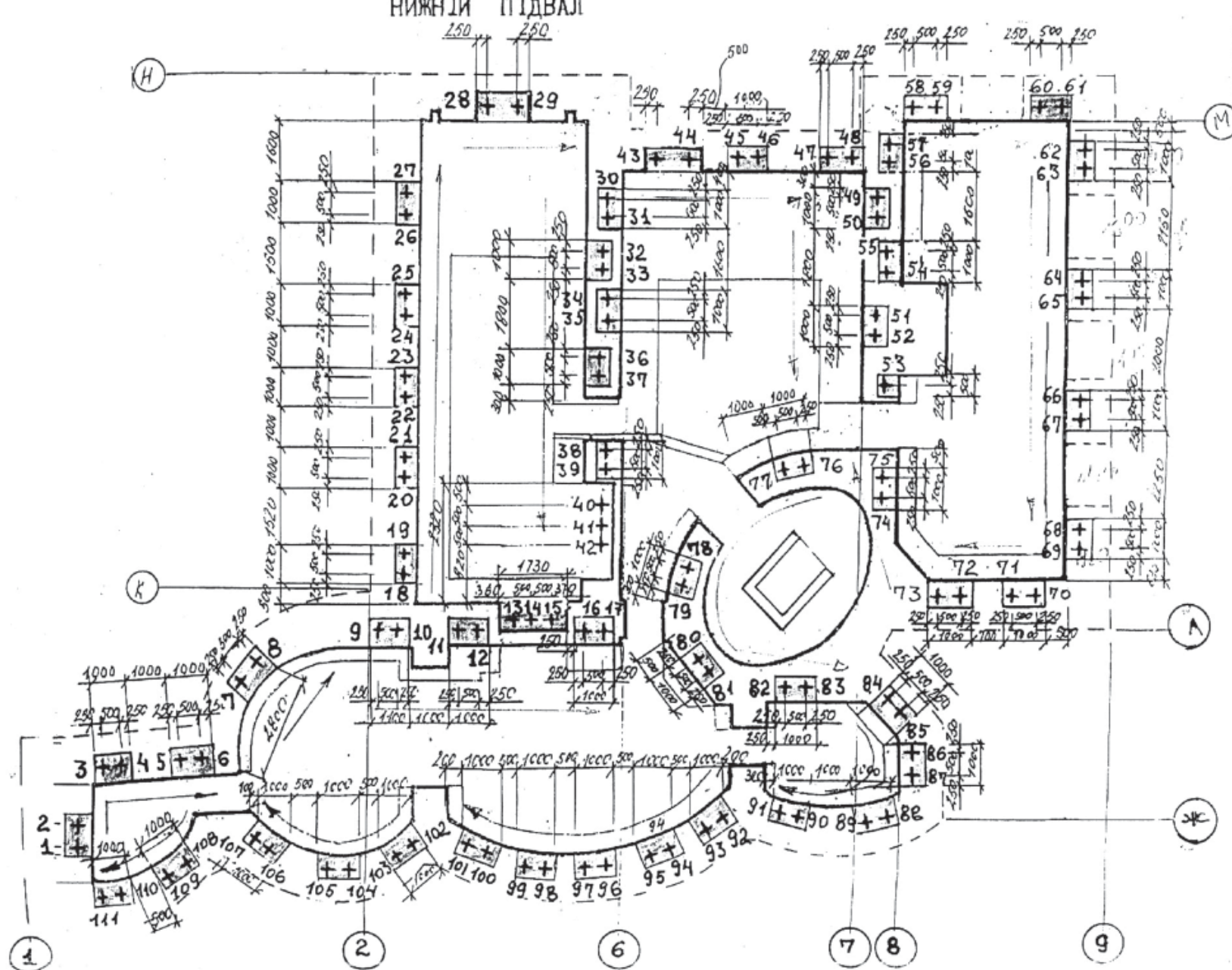

In general, the problems of the state of all three objects were as follows. In the house of L. Rodzianko at 14-b Yaroslavov Val Street, these problems related to changes in the appearance of the main facade and interiors of the owner's apartment as a result of numerous repairs and repainting, damage of certain sections of lime-sand plaswer, poor technical condition of the gypsum stucco decor; wetting and moistening of the gypsum layer of plaster; drying out and destruction of the timber paneled doors: under windows and balconies in the soaked places, biological damage of the board and wooden lath was ob- served; the easel painting and "alfresco marble" of the main staircase, required restoration (III. 3). The issues of restoration of the Kachkovskyi clinic a change in the authentic appearance of the main repairs and the loss of a part of the decor; the main cause of damage was the influence of atmospheric factors, which caused wetting of structures, biological damage of wetted areas, corrosion of meta fittings of sculptures and chips of surfaces. building at 33 Honchar Street were associated with facade as a result of the re-painting during previous 


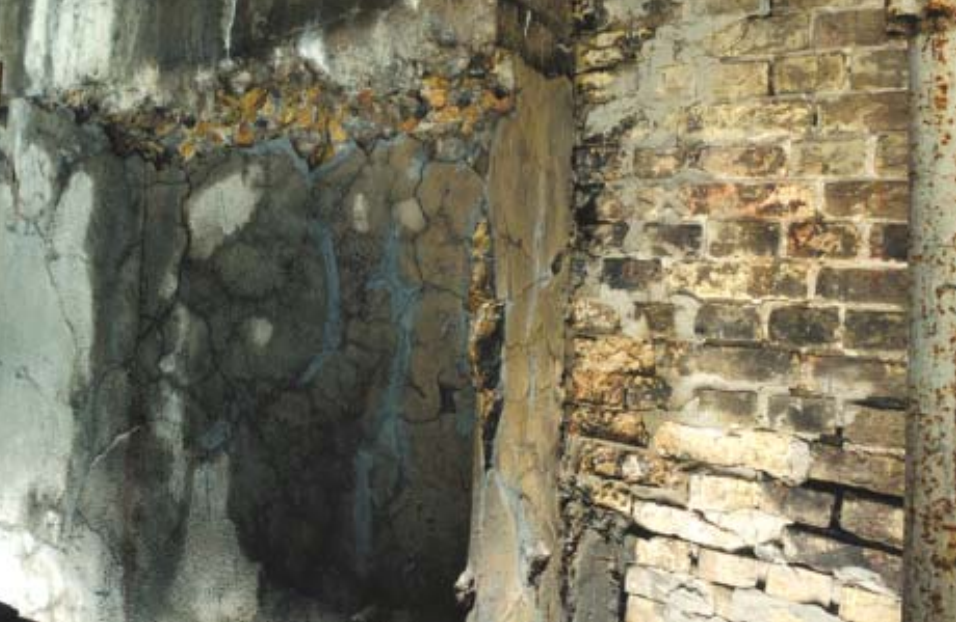

III. 7. The house at 10 Bankova Street. The
Photo: Ukrrestavratsiia corporation, 2001

The main facade of the building was covered with cracks; it was necessary to replace the waterproof-
ing of the balcony and terrace, a part of the crowned ing of the balcony and terrace, a part of the crowned metal elements and to eliminate salt efflorescence. The unsatisfactory technical condition was fixed at the top
of the cornice, brackets, decor, decorative ceramic and of the cornice, brackets, decor, decorative ceramic and
glass inserts, decorative pedestals of the basement, and sculpture of the main facade. Corrosion of metal fittings inside cement sculptures of sirens and a lion led to thei splitting into separate fragments and the loss of some parts with exposure of internal fittings; corrosion of metal fittings caused an emergency condition of the left balcony, floors of the terrace and structures of the passage to the courtyard (III. 5).

There is similarity with the causes of the emergency state of the sculptural decoration of the house at 10 Bankova Street, as will be discussed below.

The greatest number of issues arose during the restoration of the house at 10 Bankova Street. The main problem was connected with the combination of two different foundation systems without contraction joints (strip foundations from the side of Bankova Street, and from the side of the slope foundation on bored piles (firs used by an engineer A.E. Strauss), which led to uneven building subsidence - as a result the house split into two parts a thise walls were inclined hom the vertical by deformation of the floors (Figure 6).

). Yare more issue the for 14 sociated with wetting, but in the case of the hous at 10 Bankova Street, it was continuous significant soil moistBaning of the footing under foundations, which led to uneven subsidence of the foundations and walls, chipping of the surface of the front masonry, biological damage of all surfaces of the northern facade and basement floo and disruption of the paint layer.

The subsidence phenomena caused the activation of cracks mainly on the north and south facades with a tendency for further disclosure, including masonry disturbances and bricks falling out. the emergency condition of the balconies of the southern facade of the house of W. Horodecki at 10 Bankova Street, with the destruction of con-
crete, corrosion of the internal reinforcement of the monolithic reinforced concrete balcony slab and decorative balustrade, was caused by wetting through atmospheric humidification, in this case, the emergency condition of the zinc covering of the roof, wetting of wooden roof structures and floor due to biological damage of the beams. Humidification of walls masonry and, consequently, penetration of atmospheric moisture into the thickness of rustic through the surface cracks and pores and metal corrosion inside the rustics led to an emergency condition the basement cement mortar rustications with imitation under the clumps of natural crushed stone, with the appearance of hrough cracks, loss of cement sandy mortar and seasonal biological damage. Humidification and sedimentary processes led to the destruction of the cement decor of the facades, the appearance of cracks, erosion and biological damage. Atmospheric and groundwater moistening resulted in the loss of a decorative overlay dark gray cemen roller for joints pointing in masonry on almost al
facades (III. 7). Just as the ceramic decor of the Kachkovskyi cliic was in an unsatisfactory condition, the decor of in the form of decorative mirrors, lined with dark gray-green (marsh) glazed was in somewhat better condition (han the glazed was in somewhat better chipped glaze and ceramics, pollution and salt efflorescence.

The cause of the emergency state of the cement-sand facade decoration of the house at 10 Bankova Street, as well as of the building of the Kachkovsky clinic, was the corrosion of internal metal reinforcement, which led to the appearance of cracks and loss of fragments of sculptures (IIII. 8). the same time period, you can set a characteristic list of various masonry mortars (cement, cement-lime-sand, cement-sand mortar layer, cutting the plaster laver into thin rustics (the house at 10 Bankova Street): siding of

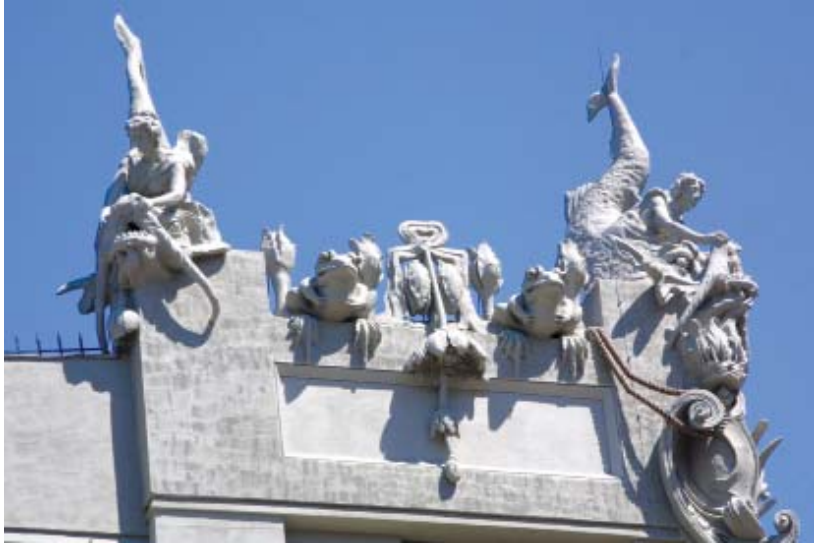

III. 8. The house at 10 Bankour Strest. a-b. The condition of the sculptures of facade before the restoration.
c. The condition of the sculptures of facade efter the restoration
Matherials of Ukrrestavratsiia corporation, 2001-2003

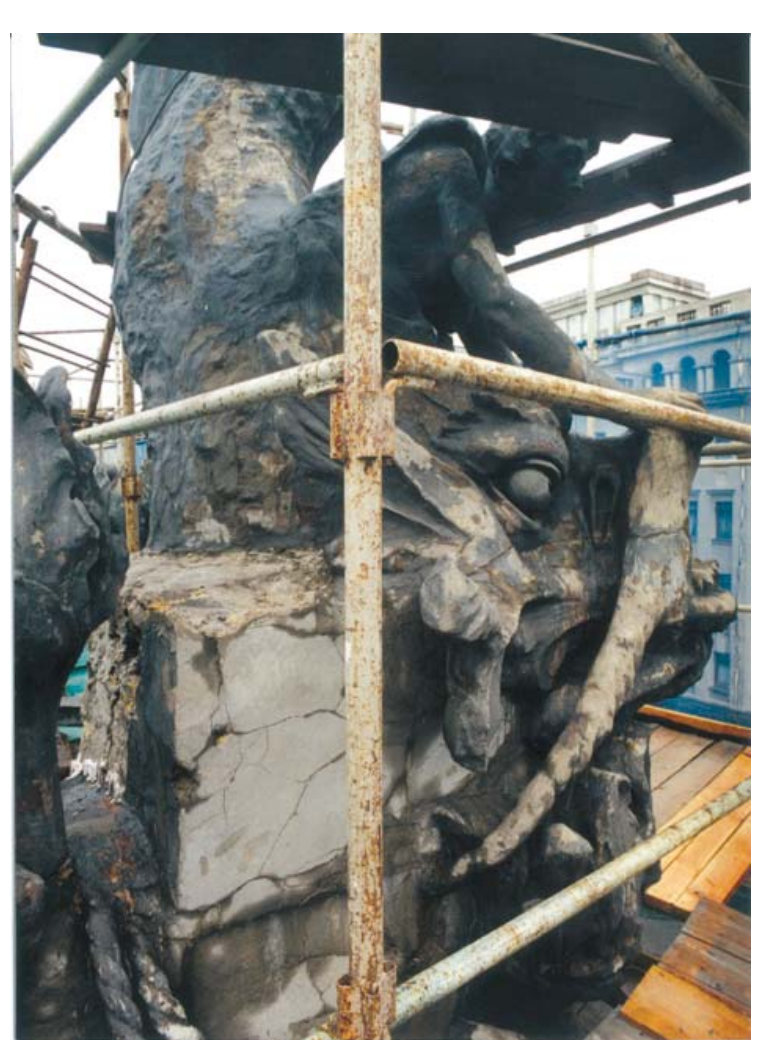

Based on the comparison of the houses at 33 Honchar Street and at 10 Bankova Street and their belonging to building materials of the tenement housing of Kyiv in the early twentieth century.

The walls were erected from yellow Kyiv brick using lime-sand) (the house at 10 Bankova street), use of gray portland cement (the house at 10 Bankova street) and color (red, pink, gray-pink) (the Kachkovskyi clinic). During the Secession period in Kyiv, the basement part was made in a peculiar way: a basement with reinforced ferrous metal strips with rustic of cement mortar with imitation under clumps of natural crushed stone (the ouse at manka stre method of toorolive tecolive Kachkovsyi linic).

They applied coloring of plastered surfaces and decoratof dark gray color (the house at 10 Bankova Stret), paint ing with cement, paste-like cement-sand and oil paints (the house of Kachkovskyi clinic). There were diversified facades: fine bush hammer finishing of the plaster layer, smoothly plastered surfaces, scrape processing of the the high-relief columns with plaster layer of small grained palladiana white cement mortar with red ocher and filling compound( the building of Kachkovskyi clinic).

The facade stucco decoration was made of cementsand mortar with internal metal fittings (the house at 10
Bankova Street, the house of Kachkovskyi clinic), Of cement mortar of homogeneous dense structure (the Kachkovskyi clinic).

Conclusion

The study of city development in the centers of the concentrated location of residential objects of the Secession style in Ukraine, enabled substantiating the influence of the style on the formation of architectural ensembles of the streets, squares, residential complexes, as well as on individual objects in the building of the streets; to reveal the significance of he main detalls or the object of architeccone and envich

an early stage, the manifestation of the stylistics 列 environment and changing the doming the urban but at a late stage, the main attention is no longer focused on the decoration of facades and interiors, but on solving compositional planning tasks as part of a separate object, residential complex as a whole, inner courtyard space.

The decisive influence on the concentration of obects of Secession in the structure of the cities was made by the principles of urban development: the medieval narrow parceled along the frontage lines in Kyiv. The zones of concentration of the monuments of the Secession architecture in Lviv are located outside the medieval city limits, in Kyiv they in Lviv; the rigid perimeter along the frontage lines 
are built along the main streets. Within the designated zones of concentration of monuments of the Secession architecture in Lviv, the building ensembles of Asnyk Street (Acad. Bohomolets St.), Domagalychi Street (Acad. Pavlov St.), Hlynianska Street (D. Dontsov St.) Fridrikhiv Street (Martovych St.), Yablonovski Street (Shota Rustaveli St.), Lenartovych Street (Nechui-Levytskyi St.). In Kyiv, there are five zones of concentration of monuments of the Secession architecture with location of the objects along the main streets: within the historic center between Lviv Square and Khreshchatyk, from Yaroslaviv Val Street towards B. Khmelnytskyi Street and Peremoha Square; along Vietrova St., Saksahanskyi St. and Zhylianska St., Pushkinska St., and Khreshchatyk in the direction of L. Tolstoi St. and Saksahanskyi St., and the fifth - on Pechersk, from Khreshchatyk in the direction of the streets of Hrushevskyi, Bankova and Institutska.

\section{BIBLIOGRAPHY}

[1] The architectural heritage of Chernivtsi of the Austrian period: materials of the International Scientifical conference, (Chernivtsi, October 1-4, 2001) / comp. P. Rykhlo. - Ch: Zoloti Litavry, 2003. - 171 p.

[2] Barer, S.D. (1981) Architecture of the small cities of Galicia and Podolia in the 19th - beginning of the 20th. / Barer, S.D. - NTE, 1981, 6. - pp. 48-54.

[3] Bevz, M. Urbanistic transformation of the central part of the city of Lviv in the 19th -20 th centuries. [Architecture of Galicia of the 19th -20 th centuries]: Selected materials of the international symposium on May 24-27, dedicated to the 150th anniversary of the foundation of the State University "Lviv Polytechnic" - L., 1996. - pp. 51-69.

[4] Vuitsyk, V.S. (1987) Meeting with Lviv / V.S. Vuitsyk \& G.M. Lypka. - L.: Kameniar. $-128 \mathrm{p}$

[5] Ivashko, Yu. V. (2007) Art Nouveau in the architecture of Kyiv / Ivashko Yu. V. - M.: Gopak,. - 240 p.

[6] Historical and architectural atlas of Lviv. House of the"Dniester" society. - L.: Center of Europe, 1996. -p.11.

[7] Historical and architectural atlas of Lviv. Chamber of Commerce and Industry. - L.: Center of Europe, 1998. - p. 19.

[8] History of Lviv, (2007). In 3 volumes. V. 2. 1772 - October 1918. - L.: Center of Europe. -559 p.
[9] Kyrychenko, E.I. (1982) Russian architecture of the 1830-1910s / E.I. Kyrychenko - Moscow. : Iskusstvo. -400 p.

[10] Kotlobulatova, I. (2008) Residents of Asnyk Street/ I. Kotlobulatova // Halytska Brama. 2008. 7-9 (163-165). - pp. 2-3.

[11] Report on the scientific expedition (from May 23 to June 25 1950) on the topic: Architecture of the Chernivtsi region of the Ukrainian SSR. - K., 1950. - 23 p.

[12] Monuments of the urban planning and architecture of the Ukrainian SSR: Illustrated Catalogue-Guide. : in 4 volumes. - K., Budivelnyk, 1983. - Vol. 1-4

[13] The plan of the center of the city of Lviv, 1936 - 1 map.

[14] Plan of Lviv. - L.: Prosvita, B. g. - 1 map.

[15] Issues of the urban planning of Western Ukraine. Abstracts of the international conference dedicated to the 80th anniversary of the Department of Urban Development of the State University "Lviv Polytechnic". - L.: Lviv Polytechnic, 1994. - 216 p.

[16] Rychkov, P.A. Town-planning evolution of Stanislav in the 17th 19th centuries. / Petro Rychkov // Architectural Heritage of Ukraine. - 2002. - 5. - pp. 196-209.

[17] Tymanovich, Ye. (1959). Report on the trip to the cities of. Lviv and Uzhgorod in the month of April 1959. / Ye. Tymanovich - K.: Acad. Archit. USSR, Institute of history and theory of arch., 1959. - 45.

[18] Kharchuk, Kh. Passage of Mykoliash / Kh. Kharchuk // Architectural Bulletin. - 2002. - 2 (15). - pp. 32-36.

[19] Kharchuk, Kh. Architectural and urban-planning ensemble of Bogomolets street / Kh. Kharchuk // Halytska Brama. - 2008, 7-9 (163-165). - pp. 4-13.

[20] Khokhol, Yu. F.,(1966) Chernivtsi. Historical and architectural essay / Yu. F. Khokhol - K.: Budivelnyk, 79 p.

[21] Chernivtsi. - Photo album. - / [Compiled by D. Tanashchyk]. Ch: Zoloti Litavry, 2006. - 127 p.

[22] Yasiievich, V.Ye. (1988) Architecture of Ukraine at the turn of the 19th - 20th centuries N.Ye Yasievich. - K.: Budivelnyk, - $184 \mathrm{p}$. [23] Yasinskyi, M. M., T. Shevchenko Ukrainian Folk House in the city of Rohatyn. / M.M. Yasinskyi // Modern Issues of Architecture and Urban Planning, 2008, 20. - pp. 108-115.

[24] Banateanu V. Fuhrer durch die Stadt cernauti / V. Banateanu, E. Knittel; Landeswacht - Gau Suceava. - Reise - Dienst. - Cernauti: Viata strajereasca, 1939. - $95 \mathrm{~s}$.

[25] Bilenkova S., Osaczuk S. Jugendstil in Czernowitz. Kalender-2003/ S. Bilenkova, S. Osaczuk. - Wien-Insbruck, 2002.- 16 s.

[26] Kaindl Raimund Friedrich, D-r. Geschichte von Chernovitz von den ältesten Zeiten bis zur Gegenwart.Festschrift zum Sechzigjärigen Regierungsjubiläum Sr. Majestät Kaiser Franz Joseph I und zur Erinnerung an die erste urkundliche Ehrwähnung vor 500 Jahren./ Raimund Friedrich Kaindl. - Chernowitz: Pardini, 1908. - 230 s.

[27] Lewicki Jakub. Miedzy tradycja a nowoczesnoscia. Architektura Lwowa lat 1893-1918 / Jakub Lewicki. - Warszawa, 2005. - 590 s. 